\title{
Enhancement of Horizontal Well Oil Recovery by Means of Chemical
}

\section{Stimulation}

\author{
Yartiev A. F. ${ }^{1,2}$, Musabirov M. H. ${ }^{2}$, Tufetulov A. M. ${ }^{1}$ \& Grigoryeva L. L. ${ }^{3}$ \\ ${ }^{1}$ Kazan Federal University, Institute of Management, Economics and Finance, Kazan, 420008, Russia \\ ${ }^{2}$ TatNIPIneft Tatar Oil Research and Design Institute of OAO TATNEFT, 423236, Bugulma, Russia \\ ${ }^{3}$ Kazan Federal University, Institute of Language, 420008, Kazan, Russia \\ Correspondence: Yartiev A. F., Kazan Federal University, Institute of Management, Economics and Finance, \\ Kazan, 420008, Russia.
}

Received: March 19, 2015 Accepted: March 31, 2015 Online Published: April 30, 2015

doi:10.5539/ass.v11n11p346 URL: http://dx.doi.org/10.5539/ass.v11n11p346

\begin{abstract}
Complex of self production technologies solves the problem of preservation, restoration and enhancement of natural collection characteristics of bottom hole formation zone and, moreover, enhancement of active draining field and level of hydrocarbon selection by oil wells of different construction in non-uniform porous fractured carbonate reservoirs. The scientific and methodological basis for complex of well stimulation technologies in carbonate reservoirs is the following principle - phased, consistent, rational inclusion in the development and exploitation of the entire producing formation thickness, and only thereafter - successive, phased realization of physical and chemical influence on the formation-reservoirs depth and extent. The article deals with the solution of up-to-date problems of restoration and enhancement of productivity of oil wells in Tatarstan carbonate reservoirs under conditions of import substitution of advanced technologies of the formation oil recovery enhancement. Stimulation issues on the entire chain of oil extraction technological process are regarded from the formation drilling-in until repair-isolation works. Reduction in oil recovery cost is taken into account by means of the effective application of complex technical solutions, operations matching in time and power inputs on production enhancement in wells from water-bearing horizon. Enhancement of technical and economic efficiency of one's own technologies of acid treatment of vertical and horizontal wells leads to enhancement of current and final coefficient of hydrocarbon resources extraction. Solution of the above stated tasks was performed on the basis of the suggested by the authors principally new, scientifically based, mastered in production and inculcated in industrial scales complex of our own technical and technological solutions providing achievement of considerable enhancement of the efficiency of hydrocarbon raw materials extraction in Tatarstan.
\end{abstract}

Keywords: complex, technology of hydrochlorid-acid formation treatment, carbonate sediments, bottomhole formation zone treatment, enhancement of oil output, additional oil extraction, effficiency

\section{Introduction}

Generalized analysis of foreign companies activity directed at the development of stimulation shows that academic research is devoted to two main tendencies (Matrix Stimulation, 2005): on chemistry of processing materials and on technological methods of their delivery and injection into formation (Matrix Stimulation, 2005Brian \& Metcalf, 2009).

Concerning the first method, the development of acid self deflecting and self regenerating in the formation acid compositions, acids with regulated reaction kinetics with slowing down as well as acceleration of the selective reactions on mineralogical components, hydrocarbon compositions with the enhanced capacity pollutants, highly active emulsifying agents, penetrating agents and dispersants and also application of organic acids and their mixtures with inorganic.

Abroad oil service companies, as a rule, apply chemically pure hydrochloric acids with initial concentration 28-38\% of chlorine hydride with addition of from 3-4 to 10 and more special ingredients of different classes (Matrix Stimulation, 2005). Naturally, prices on such acid compositions (Clay Acid, RNF, Regular Mud Acid, Sandstont Acid, Half Strenght Mud and others) are very high. Analysis of technical and patent foreign literature 
showed that development achievements in the field of chemical stimulation of horizontal wells (HW) work is held in the direction of the complicated system of inflatable packer with relief (bypass) valves use (Coulter, 1993). HW cavity is divided into small parts in advance. Acid is cyclically directed into these pipe fields between packers, gradually, and this way the entire HW or its calculated intervals are being treated.

Halliburton, Schlumberger, Chell, Vestern, Dovell, Nowsco, Chevron Phillips, the leading foreign companies dealing with the development of acid compositions on the basis of hydrochloric acid and compositions with hydrofluoric acid, carry out research on foam-acid compositions thickened (polymers, surface active compositions) acids, acid containing emulsions, generation of acids in the formation itself. For deep influence on carbonates in the USA polymers of acryl row are used, gels on the basis of alkaline metal silicate, boric acid salts, biopolymer reagents.

Baker Huges, Schlumberger, Halliburton, McDermott, BJ Services Company created, patented and successfully continue to use for treatment their own acid solutions on the basis of pure syntetic hydrochloric acid with addition of the definite set of complex additives, organic acids which provide the enhancement of the wells outputs, preservation of the formation's collector properties, heat-resistance of compositions and protection of oil producing equipment from corrosion. However, import of such products in Russia with beginning of sanctions in the gas and oil extracting field gradually decreased.

St. James Oil Company improved acid stimulation of wells. To achieve longer efficiency of hydrochloric acid treatment, phosphonic acid with hydrochloric acids are injected.

Exxon Mobil - stimulation of powerful carbonate formations, injection strategy, calculating and modelling of acid treatments, HF projecting.

Chevron - методы оценки нарушений эксплуатационных качеств пластов, химия для соляно кислотных обработок (СКО) и ГРП.

Chevron - methods of operational formation qualities disturbances evaluation, chemistry for hydrochloric acid treatments and HF.

Saudi Aramco - mechanism of acid reactions, acid treatment of dense matrix blocks, mechanism of rock etching by acids of different modifications.

Acid jet technologies StimTunnel, PVDSA, BJ Services Company - are technologies of arborescent well building (with several open side tracks) in carbonate reservoirs allowing to enhance the filtration surface area with further oil recovery. In fact, this technology of rock erosion by acid in open track and well creation containing basic track with many subsidiary tracks on different levels, each of which contsisting of smaller fractal channels formed from penetration of acids and dissolution of rock. Example of arborescent well is presented in Figure 1 (Espina, Guerrero, Colmenares, Dias, Rae, \& Lullo, 2011).

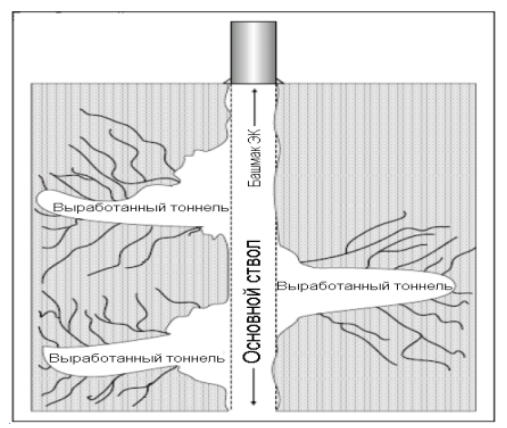

Figure 1. Arborescent well

The basic characteristic feature is high well productivity owing to hydrocarbon inflow through large surface area, there exist restrictions for technology - oil saturated formation thickness should be not less than $15 \mathrm{~m}$, rocks dissolubility - more than $80-90 \%$, the absence of water-saturated rocks, porous structure.

Jogmec-Tokio conducts research in technologies of acid HF.

Eni Exploration - complex research of objects and technologies of inflow stimulation.

Apache Corporation - the use of slowed down reaction of acetic acid under conditions of low intensity of liquid injection regulating at the same time water influx of well production. The essence of technology is based on organic acid of high concentration injection in rock with large volume of fresh water. 
Concerning second tendency, progressive development takes place and is forecast by the following methods:

- Inflow intensification by DTS method - the use of fibre optic systems as internal highly sensitive element (lazer impulse descends into fibre, the reflected light is analyzed to obtain temperatures profile along the whole fibre, visualization of well and formation processes is achieved during delivery and injection of fluids into formation);

- Technology SIGMA (selection of wells-candidates for working out by means of complex reservoir study, projecting and technologies realization);

- Technology MAPDIR (realization of maximum permissible gradients of pressure and speeds of acid compositions injection into fissured-porous reservoir).

The controlled influence on selective formation areas is considered to be the main factor. From technological point of view, it is achieved by reagents selection, control over their rheology, redistribution of processing composition, dynamic changes of injection.

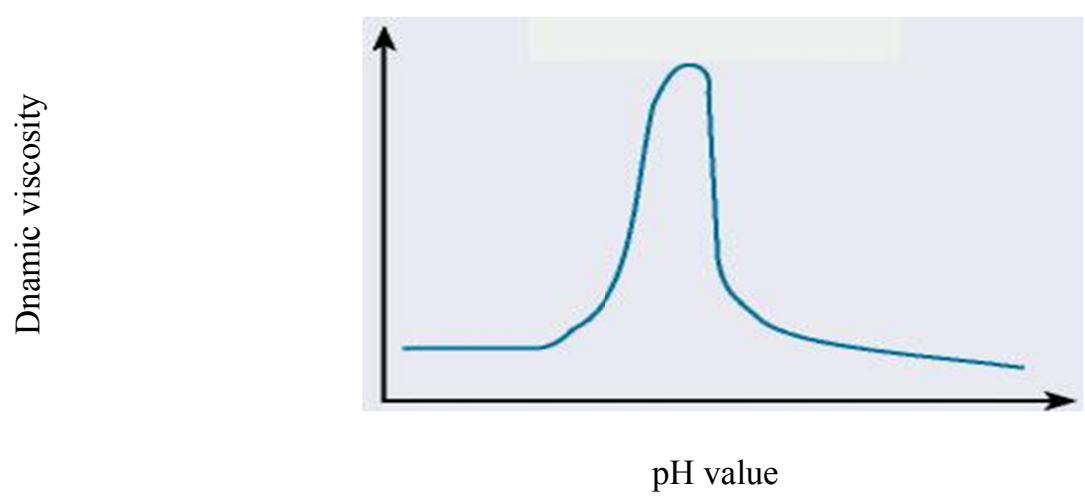

Figure 2. Viscosity of cross-linked polymer as $\mathrm{pH}$ function

Ordinary chemical deflecting technologies are based on preliminary injection of polymer gels. New acid systems are applied individually without preliminary injection of deflectors. They use $\mathrm{pH}$ change, as a result of which cross-linking additives change liquid's viscosity at design moment during acid treatment (Figure 2).

Polymer acid systems have shortcomings. Independent research conducted by Stim-Lab, FRAC TECH Services, L.L.C., Saudi Aramco and other companies showed that polymer acid systems block (clog) canals and can damage formation. Owing to narrow opening, $\mathrm{pH}$ of cross-linked polymers is difficult to control, particularly if it includes several stages and stability of polymer systems becomes worse during temperature rise in the well bottom, moreover, in acidic media hydrogen sulphide is formed.

\section{Materials and Methods}

Decrease in energetic costs under modern conditions of oil fields latest stage and development of complex technologies for oil recovery stimulation when import substitution is observed, the following tasks are put in the first place.

1. To adopt the foreign companies' experience in precise well-running organization of complex specialists groups in all problem aspects by closed chain: detailed analysis of core - analysis of the entire trade information with prehistory and statistics - process projecting and modelling - objects selection - chemical reagents binding - research and process realization under formation conditions - materials correction - development of optimal technology for the given reservoir.

2. To develop system of well stimulation technologies with simultaneous solution of the oil productivity increase problem with minimization of possible well production watering and water inflow restriction. For this purpose, to apply all physical and chemical opportunities of home improved formulae of hydrophobous emulsions and acid stimulating compositions using scientific approach.

3. The need for approval and industrial introduction of the following variants of new and modified combined technologies of well stimulation:

- technological variants of highly viscous hydrophobous emulsion injection in carbonate porous fractured reservoirs with further acid stimulation of non-working thicknesses; 
- technological variants of highly viscous hydrophobous emulsion injection in highly penetrable reservoirs with further complex shock wave and chemical stimulation of non-working thicknesses;

- technological variants of the directed acid treatment of HW intervals with water saturated zones blocking;

- technology of jet acidizing treatment of net oil thicknesses and intervals of VW and HW with preliminary restriction of water entrance in the producing wells;

- technological variants of acid HF carrying-out with preliminary isolation of possible water inflows;

- technology of water inflows isolation with further gentle acid treatment of formation with special surfactants-compositions etc.

Potential of modern complex technologies industrial introduction is great - large operating oil stock with watering until $90-95 \%$ requiring solution of simultaneous oil productivity increase and decrease in production watering. Economic effect from this project's realization in industrial variant is large-scale and will be integrally determined from essential increase in oil recovery as well as non-productive rise of incidentally extracted water.

\section{Results}

Group of authors from JSC Tatneft developed technological variants of the near-well region treatment of the producing and key wells method with compositions of new acid structure ASC (acid stimulating compositions) (technologies of ASC-Tatneft) aimed at increase in well producing opportunities and enhancement of injectivity of key wells by means of the formation filtration characteristics improvement resulted from physical and chemical influence.

Specialists of JSC Tatneft developed and approved in practice diverse technological schemes of ASC application in the main operating objects in Tatarstan. For 01.12.2014 the volume of industrial technological introduction of ASC in Tatarstan oil fields is approximately 1000 wells (Figure 3). Total value of additional recovered oil by means of the given technology application - approximately 600 thousands.

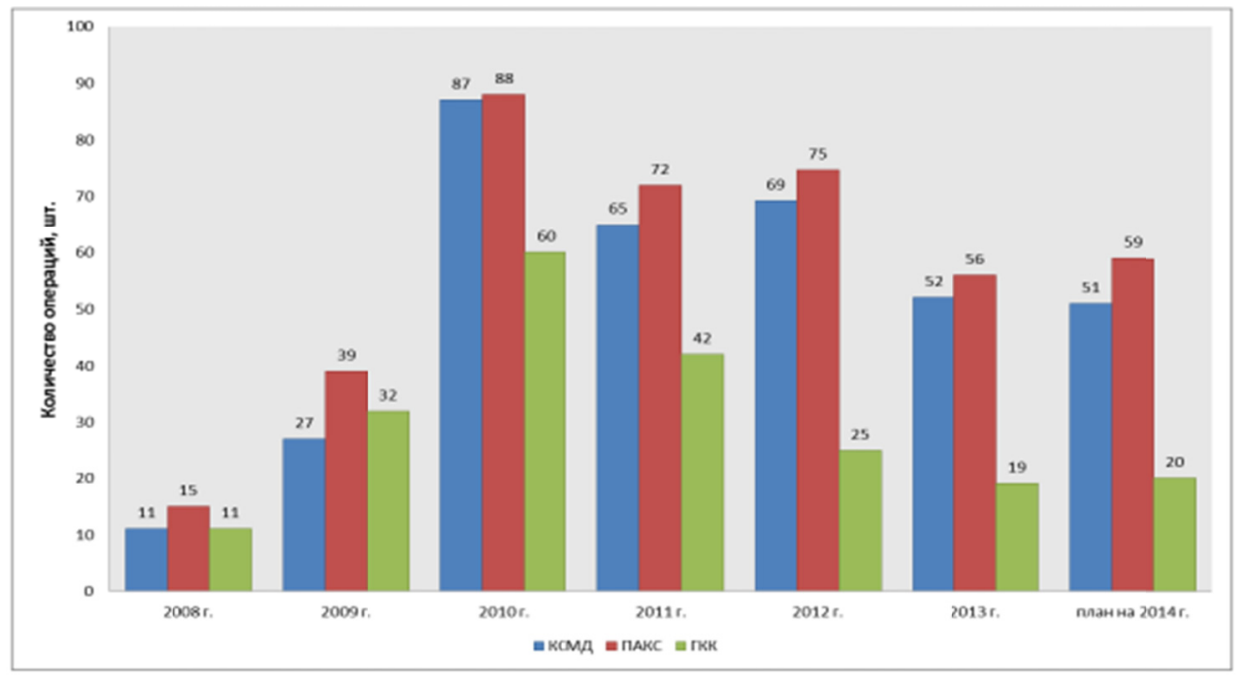

Figure 3. Industrial introduction of ASC-Tatneft technologies

In the process of different experimental variants of large volume selective acid treatment technology (LVSAT) the basic technological criteria and principles taking into account geological and physical conditions of carbonate Tatarstan objects exploitation:

a) systemic criterion - technological variants of well stimulation in time of acid compositions injection into formation with average specific charge of $3-5 \mathrm{~m}^{3}$ for one meter of exposed bed thickness - for VW conditionally and $0,2-0,5 \mathrm{~m}^{3}$ for HW conditionally.

b) the basic technological criteria (LVSAT) -injection rate of acid composition (AC) into formation $5-10 \mathrm{dm}^{3 / \mathrm{s} \text {; }}$

- obligatory deflection of AC in oil saturated intervals;

- alternation of injection of acid-dissolvent;

- application of AC combination with different reaction kinetics. 
Effect of oil output enhancement is fixed in all experienced wells, the average increase of oil output based on technology was equal 5,4 t/a day with practically invariable watering level.

As an example of successful approbation of (LVSAT) technology in HW carbonate reservoirs can be considered implementation of two well operations in well of 3010 hectares and 4927 hectares NGDU «Bavlyneft». Well operation dynamics before and after stimulation implementation in presented in Table 1.

Table 1. Dynamics of well operating 3010ha and 4927ha

\begin{tabular}{|c|c|c|c|c|c|c|c|c|}
\hline \multirow[b]{2}{*}{$\mathrm{N}$} & \multirow[b]{2}{*}{$\begin{array}{c}\text { Date of start } \\
\text { of work }\end{array}$} & \multicolumn{5}{|c|}{ Wells operation indices } & \multirow[b]{2}{*}{$\begin{array}{c}\Delta \mathrm{q}, \mathrm{t} / \mathrm{a} \\
\text { day }\end{array}$} & \multirow[b]{2}{*}{$\begin{array}{l}Q \text { for } \\
01.03 \\
2014 \\
t\end{array}$} \\
\hline & & before BZT & after BZT & $\begin{array}{c}\Delta \mathrm{Q} \text { after } \\
\mathrm{BZT}, \mathrm{t} / \mathrm{a} \text { day }\end{array}$ & $\begin{array}{c}\text { for } \\
01.03 .2014\end{array}$ & $\begin{array}{c}\Delta Q \text { for } \\
01.03 . \\
2014, \mathrm{t} / \mathrm{a} \\
\text { day }\end{array}$ & & \\
\hline 3010ha & $\begin{array}{c}08.07 . \\
2013\end{array}$ & $\begin{array}{l}\mathrm{Q}_{\text {ж}}=4,0 \\
\mathrm{~m}^{3} / \mathrm{a} \text { day, } \\
\mathrm{Q}_{\mathrm{H}}=3,5 \quad \mathrm{t} / \mathrm{a} \\
\text { day, } \\
\text { Owat. } \\
2,0 \%, \\
\mathrm{P}_{\text {заб }} \quad 34,5 \\
\text { atm. }\end{array}$ & $\begin{array}{l}\mathrm{Q}_{\text {ж}}=15 \mathrm{~m}^{3} / \mathrm{a} \\
\text { day, } \\
\mathrm{Q}_{\mathrm{H}}=13,1 \quad \mathrm{t} / \mathrm{a} \\
\text { day, } \\
\text { Owat. } \\
2,1 \%, \\
\mathrm{P}_{\text {заб }} \quad 44,0 \\
\text { atm. }\end{array}$ & 9,6 & $\begin{array}{l}\mathrm{Q}=6,0 \quad \mathrm{~m}^{3} / \mathrm{a} \\
\text { day, } \\
\mathrm{Q}=5,1 \mathrm{t} / \mathrm{a} \text { day, } \\
\text { Wat. 5,0 \%, } \\
\text { P 37,0 atm. }\end{array}$ & 1,6 & 3,2 & 686 \\
\hline 4927ha & $\begin{array}{l}17.08 \\
2013 \Gamma .\end{array}$ & $\begin{array}{l}\mathrm{Q}=6,8 \mathrm{~m} 3 / \mathrm{a} \\
\text { day, } \\
\mathrm{Q}=5,9 \quad \mathrm{t} / \mathrm{a} \\
\text { day, } \\
\text { Wat. } 4,0 \% \text {, } \\
\text { P 39,5 atm. } \\
\text { Total }\end{array}$ & $\begin{array}{l}\mathrm{Q}=15 \quad \mathrm{~m}^{3} / \mathrm{a} \\
\text { day, } \\
\mathrm{Q}=13 \quad \mathrm{t} / \mathrm{a} \\
\text { day, } \\
\text { Wat. 2,7\%, } \\
\text { P } 50 \text { atm. }\end{array}$ & 8,4 & $\begin{array}{l}\mathrm{Q}=12,5 \quad \mathrm{~m}^{3} / \mathrm{a} \\
\text { day, } \\
\mathrm{Q}=10,9 \quad \mathrm{t} / \mathrm{a} \\
\text { day, } \\
\text { Wat. 2,5\%, } \\
\text { P } 49 \text { atm. }\end{array}$ & 5,0 & 7,5 & 1361 \\
\hline
\end{tabular}

Average increase in oil output immediately after BZT in two wells 3010ha, 4927ha was 8.4 t/a day, on condition for 01.03.2014 - $3.3 \mathrm{t}$ /a day taking into account the completed time 406 days in two wells -5 t/a day. Additional recovery for this period was $2047 \mathrm{t}$ of oil. Effect stably continues.

Technology of cyclically directed SD of horizontal wellbore with use of highly viscous hydrophobous emulsions allows to make selective treatment of any HW section. It is possible to treat selectively several bore sections, several successively situated sections in any bore part and even the entire bore of any length in cyclically directed regime by acid under regulated pressure as well as without pressure (acid bath).

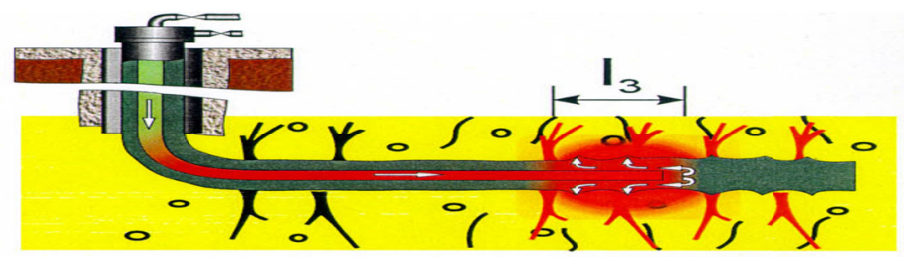

Figure 4. Acid injection in calculated interval of HW after hole filing with highly viscous emulsion: $\mathrm{I}_{3}$ interval of treatment zone

The developed methodics includes the following operations: the change of well liquid for the reverse HW emulsion; installation of production tubing casing shoe into the furthest end of HW intended for BZT; injection in production tubing of acid and its intrusion in interpipe space in volume equal to circular space in length of the treated section; intrusion of acid into formation. Acid intrusion from production tubing is implemented by reverse emulsion (figure 4). Then treatment of the next section is implemented, the most optimal length of one section being 20-25 m. Technology is protected by RF patent for invention (Chepick \& Musabirov, 2006). The first formation BZT for the given method was implemented in well 592ha of Onbiysk oil field. Before treatment the well with HW with length of $250 \mathrm{~m}$ had output of 6-8 t/a day with dynamic level 1015-1050 m. In the well interval treatment of the remote hole on $100 \mathrm{~m}$ length ( 4 cycles $25 \mathrm{~m}$ each) was conducted. For treatment inhibited $15 \%$ hydrochloric acid with specific consumption of 20-22 $\mathrm{m}^{3} / \mathrm{a}$ day at dynamic level in the hole mouth. Effect stably lasted for several years. Additional oil recovery was more than $20000 \mathrm{t}$. 


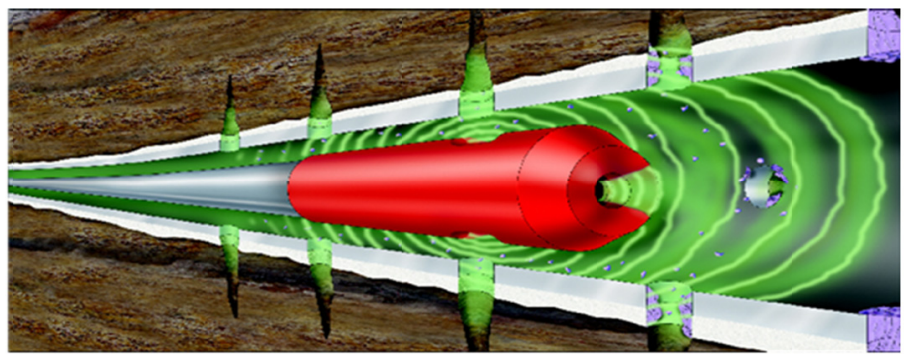

Figure 5. Schematic illustration of technology

The main technical advantage of well acid stimulation technology in dynamic regime with application of coil tubing is the possibility to inject acid solutions in the formation in calculated interval of HW with simultaneous shift of the continuing tube's shoe along horizontal wellbore. As a result even treatment of the bore along the entire length and diameter is provided. The innovativeness and the level of the given solution (Orlov \& Musabirov, 2001) allows to achieve new technical effect, particularly uniform circular acid supply on HW surface by means of simultaneous shift of the casing column along HW axis and rotation of acid flow at exit from the chasing shoe realization. In this hydrodynamic regime uniform acid treatment of $\mathrm{HW}$ along its length and side bore surface is provided (Figure 5). Technical economic studyings showed that this method is distinguished by economy in costs of the used liquids, acid, as well as in costs of the BZT method itself. Not less than 2-3 days of the capital well repairing brigade's work are saved, the necessity of preliminary operations of the appiled liquids preparation falls away. The increase in the wells' output on oil in average from 2.5 to 5 t/a day is achieved with significant decrease in labor costs. Effect in wells stably lasts for several years.

Analysis shows that frequently relatively highly penetrable formation intervals are acid treated, and low penetrable dense oil saturated HW sections remain practically untreated. The purpose of the new technology of acid hydromonitor-jet influence on formation in HW development is the enhancement of the efficiency of carbonate productive formations treatment by means of complex mechanical and chemical influence on dense oil-saturated (not involved in operating) intervals of open bore.

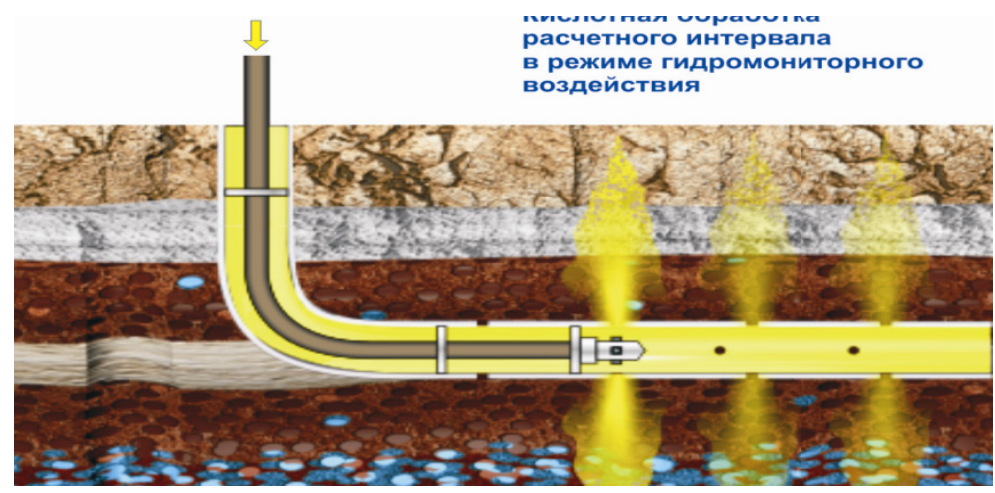

Acid treatment of calculated interval under hydromonitor influence conditions

Figure 6. Illustration of jet acid reservoir treatment

Technology is based on the fact that in the well intervals of treatment in oil-saturated rocks are planned in advance, and chasing shoe of the oil well tubing is equipped with device with hydromonitor nozzles radially placed under degees of $90^{\circ}$ or $120^{\circ}$, and acid injection in well is carried out in portions using regime of hydromonitor influence alternating acid portions with portions of surfactants water solution with the help of which hydrojet influence on formation is carried out, the alternating of acid hydromonitor and hydrojet influence being carried out in turn in the middle of each treatment interval (Figure 6). The enhancement of acid influence on these intervals is achieved by means of quality structure change of the factors influencing the rock, namely acid flow gains jet vortical and cutting properties (jets' velocity at exit of hydromonitor nozzles is more than 100 $\mathrm{m} / \mathrm{s}$ ), not losing chemical activity. Addition of surfactants into liquid mixture enhances abrasive and demolishing effect by means of disjoining Rehbinder effect. Field trials of new technology of acid hydromonitor influence on open bore of HW and VW showed high efficiency - the enhancement of well outputs from 3 to 10 t/a day.

In JSC Tatneft import changing technology of acid tunneling with use of coil tubing establishment for enhancement of HW prodictivity with open bottom. The technology's essence is realization of controlled 
relatively deep mechanical and chemical influence on non-working dense oil saturated HW intervals by means of hydrojet and acid hydromonitor influence combination of intervals with formation of a set of relatively short side canals of small diameter in carbonate reservoir. Hydraulic deflector for flexible pipe OGGT-60 (Figure 7) is intended for delivery of hydromonitor nozzle in the given point of horizontal region of open bore. Hydromonitor nozzle (Figure 8) has diameter of $65 \mathrm{~mm}$ and 7 open holes with diameter of $2 \mathrm{~mm}$ for liquid supply.

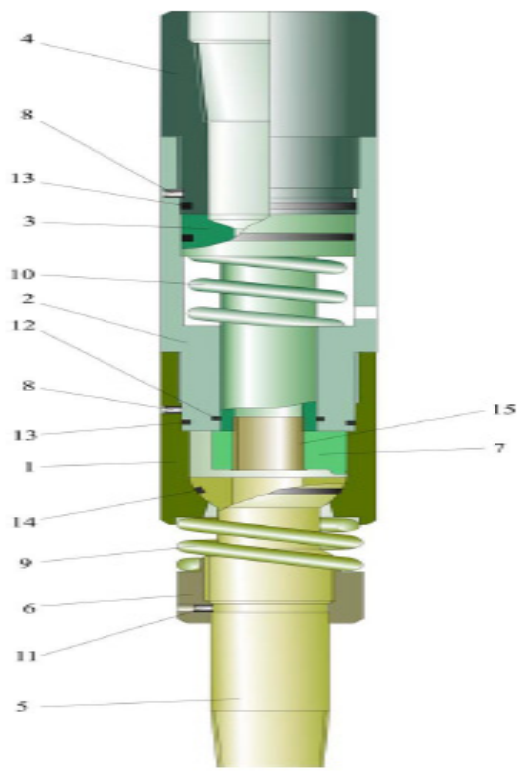

$$
\begin{aligned}
& \text { 1-case; } \\
& \text { 2-hydraulic cylinder; } \\
& \text { 3-piston; } \\
& \text { 4-adaptor; } \\
& \text { 5- nipple; } \\
& \text { 6-stay nut; } \\
& 7 \text { - eccentric pusher; } \\
& \text { 8, 11-pins; } \\
& \text { 9, 10-spring; } \\
& \text { 12-14-rubber seals; } \\
& \text { 15- bush }
\end{aligned}
$$

Figure 7. Hydraulic deflector OGGT - 60 organization
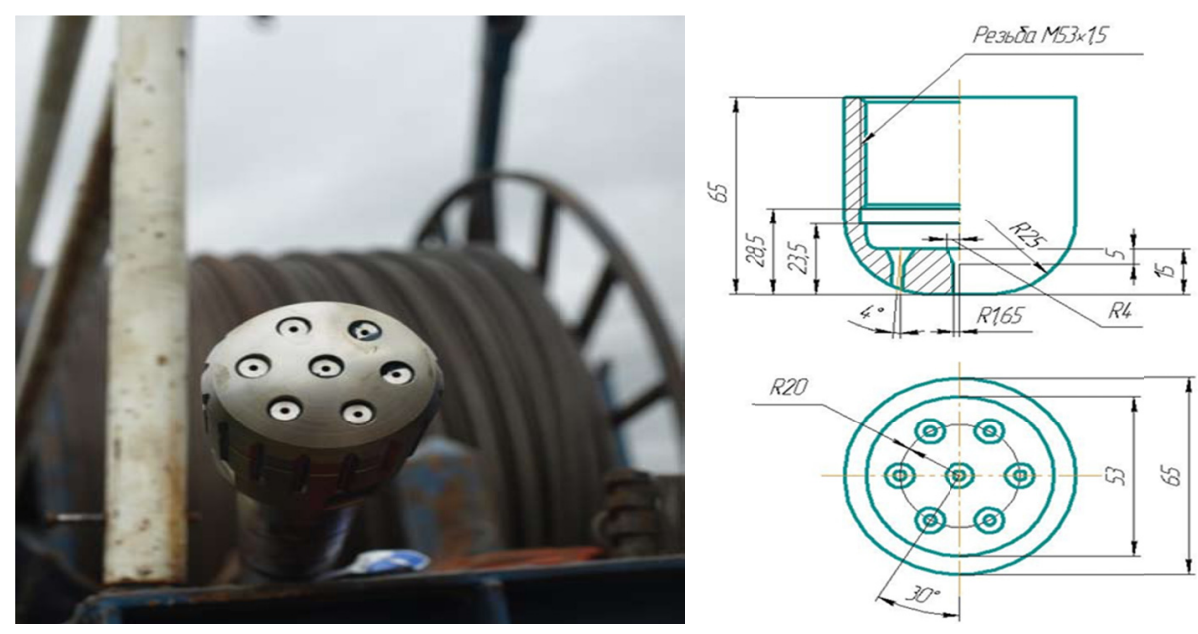

Figure 8. Hydromonitor nozzle

Oil output in the wells increase is achieved, the effect in wells stably continues. 40 well operations with total technological effect of $175000 \mathrm{t}$ of oil are carried out.

Technology of selective BZT based on self deflecting acid compositions with cationic surface active agent is carried out by successive cyclic injection in well of viscous elastic surfactant solutions portions, self deflecting acid composition and hydrochloric acid. On the basis of self deflecting composition lies its ability to repeatedly increase viscousity during the reaction with carbonate formation rock. The gel formed as a result provide effective local deflection of new AC portions to earlier untreated oil saturated low penetrable regions. An example of successful implementation of technology in NGDU Bavlyneft in the wells of 4488ha and 4859ha is presented in table 2. For production of BZT interval of HW open bore double packer system with application of hole annular space of Tam Internation company was first used (further they passed to new Russian analogue packer Quart, produced in Kazan). 
Table 2. Wells of $4488 \mathrm{H}$ and $4859 \mathrm{H}$ operation dynamics

\begin{tabular}{|c|c|c|c|c|c|c|c|c|}
\hline \multirow[b]{2}{*}{ № well } & \multirow{2}{*}{$\begin{array}{l}\text { Date of start of } \\
\text { work }\end{array}$} & \multicolumn{5}{|c|}{ Wells operation indices, $\mathrm{t} / \mathrm{a}$ day } & \multirow{2}{*}{$\begin{array}{c}\Delta \mathrm{q}, \mathrm{t} / \mathrm{a} \\
\text { day }\end{array}$} & \multirow{2}{*}{$\begin{array}{c}\text { Q for } \\
01.03 .2014, \mathrm{t}\end{array}$} \\
\hline & & $\begin{array}{l}\text { q before } \\
\text { BZT }\end{array}$ & $\begin{array}{l}\text { q after } \\
\text { BZT }\end{array}$ & $\begin{array}{c}\Delta \mathrm{q} \text { after } \\
\mathrm{BZT}\end{array}$ & $\begin{array}{l}\text { Q for } 01.03 . \\
2014 \Gamma .\end{array}$ & $\begin{array}{c}\Delta q \text { for } \\
01.03 .2014\end{array}$ & & \\
\hline 4488ha & 08.07 .2013 & 1,2 & 10,3 & 9,1 & 7,1 & 5,9 & 6,9 & 1617 \\
\hline 4859ha & 28.08.2013 & 2,1 & 10,4 & 8,3 & 7,2 & 5,1 & 5,7 & 901 \\
\hline \multicolumn{4}{|c|}{ Total } & 8,7 & & 5,5 & 6,4 & 2518 \\
\hline
\end{tabular}

The essence of technology lies in the following. In the zone of producing formation in oil-well tubing column double packer arrangement with use of inflatable packer descends. Arrangement is placed with fixed interval of HW open bore starting from toe. Further acid treatment with use of special acid compositions allowing deep penetration in the oil-bearing collector zone is produced. Then double arrangement with inflatable packers is moved to the next interval of open bore closer to heel with region's treatment with acid compositions. Such an operation is repeated several times depending on the open length of HW bore.

In table 3 dynamics of the main wells operation before and after BZT on application of foam acid BZT is presented. Priority of the developed objects - the reduced formation pressure, Tournaisian sediments. Average daily output increase for the operational period in three successful wells was $+3,1 \mathrm{t} / \mathrm{a}$ day (on the level of technologies PAKS, KSMD). In well 9304ha NGDU Nurlatneft and 16024ha NGDU Yamashneft, 9304ha NGDU Nurlatneft, 15289ha NGDU Leninogorskneft - negative result, there occured production watering. In wells 35396ha NGDU Leninogorskneft, 17507ha NGDU Yamashneft - insignificant result.

Table 3. Results of foam acid BZT

\begin{tabular}{|c|c|c|c|c|c|c|}
\hline \# well NGDU & Horizon & $\begin{array}{c}\mathrm{Q}_{\mathrm{liq},} \\
\text { before/after }\end{array}$ & $\begin{array}{c}\mathrm{Q}_{\text {oil, }} \\
\text { before/after }\end{array}$ & $\begin{array}{c}\mathrm{P}_{\text {form, }} \\
\text { before/after }\end{array}$ & $\begin{array}{c}\mathrm{P}_{\mathrm{bore}} \\
\text { before/after }\end{array}$ & $\begin{array}{c}\text { K } \\
\text { before/after }\end{array}$ \\
\hline $\begin{array}{l}\text { 35396ha, } \\
\text { Leninigorskneft }\end{array}$ & bashkir. & $0,8 / 6,5$ & $0,8 / 2,9$ & $63 / 63$ & $18 / 30$ & $0,018 / 0,197$ \\
\hline $\begin{array}{l}\text { 16024ha, } \\
\text { Yamashneft }\end{array}$ & bashkir. & $5 / 13$ & $4,1 / 0$ & $90 /-$ & $31 / 103$ & $0,085 / 14,4$ \\
\hline $\begin{array}{l}\text { 4582ha, } \\
\text { Bavlyneft }\end{array}$ & Tourn. & $4,2 / 12$ & $3,9 / 11$ & $46 / 45$ & $36 / 37$ & $0,46 / 1,375$ \\
\hline $\begin{array}{l}\text { 4583ha } \\
\text { Bavlyneft }\end{array}$ & Tourn. & $5,5 / 12,5$ & $4,8 / 11$ & $44 / 46$ & $38 / 36$ & $0,8 / 1,05$ \\
\hline $\begin{array}{l}\text { 17507ha, } \\
\text { Yamashneft }\end{array}$ & Tourn. & $1,1 / 2$ & $0,9 / 1,7$ & $31 / 31$ & $24 / 28$ & $0,157 / 0,667$ \\
\hline $\begin{array}{l}\text { 9304ha, } \\
\text { Nurlatneft }\end{array}$ & Tourn. & $1,5 / 23$ & $0,8 / 0$ & $60 / 69$ & $25 / 69$ & $0,045 / 25,6$ \\
\hline $\begin{array}{l}\text { 15289ha, } \\
\text { Leninogorskneft }\end{array}$ & Tourn. & $1,6 / 1$ & $1,3 / 0,8$ & $65 /-$ & $29 / 29$ & $0,113 /-$ \\
\hline
\end{tabular}

Resuming the above said, it is possible to make certain conclusion that new technological approaches being developed at present in JSC Tatneft in the field of oil inflows stimulation and wells BZT in complexly built porous fractured carbonate reservoirs have a perspective to become basic geological and technical events and solve the given tasks on intensification of hydrocarbon recovery.

\section{Discussion}

Analysis of modern state of the filtration capacity properties (FCP) of the downhole formation zone (DFZ) during wells opening, mastering, exploitation and repair and also generalization, systematization of BZT technologies and wells stimulation allowed to substantiate perspective tendencies of their development and work out methodology of their systemic, complex application on the entire technological chain of well exploitation in carbonate reservoirs. Analysis indicates the following priority of the most important tasks (Musabirov, 2007).

1. Quality opening (initial and secondary) of producing formation. The problem must be solved by means of industrial operation of irrigating solutions and perforation liquids, penetration of which or their filtrates in DFZ does not have negative influence on FCP (Kazemi, 1969). 
2. Effect achieved from quality formation opening must stay during the operational period. It becomes possible by means of special technological liquids application during repairing works with minimal influence on reservoir properties of DFZ (Renard \& Dupuy, 1990).

3. Preservation of thermodynamic steadiness of DFZ. Inadmissible:

- critical depression-repression disturbances in this formation zone (result - irreversible formation deformations, change in porous structure into negative side, decrease in hydroconductivity etc.)

- DFZ supercooling (result - possible appearance of organic asphaltene-tarry, paraffin and inorganic illuvial sediments) (Pobert, 1983);

- Excessive decrease in hole pressure (result - water conus pulling up, production's watering, phase changes, sand development and other negative phenomena).

Complex approach, management and regulation of quantity and fluid inflow to HW quality (Joshi, 1988; Peaceman, 1983):

- quality initial formation opening with optimal-effective geometry of borepath with preservation of FCP reservoir;

- constructing of downhole with maximum filtration area;

- engineering projecting of rational installing of cut off packers regulating fluid inflow from fractured zones of HW;

- obligatory removal of illuvial components of drilling fluid from HW side;

- stimulation of fluid inflow with HW oil saturated intervals and its whole length, when it is necessary carrying out of reliable WW with fractured as a rule water-bearing intervals cutting off.

- optimization of energetic parameters of inflow process (optimal balance of formation and hole pressures); thus, regulation of water free operational period and water content in production;

- exclusion of negative effect of FCP formations of water technological liquids during repairing works.

\section{Conclusion}

On the bais of BZT complex of new and improved technical and technological solutions was industrially introduced in oil fields providing systemic successive implementation of import substituting block technologies:

- Selective (controlled) chemical formation BZT on the basis of so called "smart" "self deflecting" AC of the last generation and polymer compositions with chemical cross-link and destruction (regulated behavior rheology):

- Methods of complex jet acid, shock wave, dynamic formations BZT, physical and chemical and hydro-impulse influence on DFZ of uneven (heteragenous) in structure and penetrability of reservoirs;

- Regulation of oil and water selection (technologies of water inflows isolation in VW and HW, complex stimulation technologies with simultaneous restriction of water inflow).

Within realization technical and technological solutions provided the following indices of technological and economic efficiency and social effect in regions of inductrial works carrying out (Ibragimov, Musabirov, \& Yartiev, 2014).

- introduction in 1163 wells;

- -995 th. t; additional oil recovery - $995000 \mathrm{t}$;

- total effect from oil recovery stimulation technologies was 1.5 billions roubles;

- additional payments in budget and non-budgetary funds in RF are estimated in 9.3 billions roubles;

- multiplicative effect taking into account adjacent fields was estimated in 19.1 billions roubles;

- reduction in staff in main production is absent since company's oil recovery remains on the level achieved and even increases.

\section{References}

Babadagli, T., Al-Bemani, A., \& Boukadi, F. (1999). Seawater as IOR fluid in fractured chalk. Paper SPE 93000 presented at SPE International Conference on Oilfield Chemistry, Houston, Texas, USA, 2-4 February.

Brian, C., \& Metcalf, S. (2009). Oil recovery intensification in San Anders district owing to weak acid application. Oil and gas technologies, 12, 21-25. 
Chang, F. F., Qu, Q., \& Miller, M. J. (1999-2002). US 6399546 B1. Fluid system having controllable reversible viscosity. Schlumberger Technology Corporation.

Chang, F., Qu, Q., \& Frenier, W. (2001). A Novel Self-Diverting Acid Developed for Matrix Stimulation of Carbonate Reservoirs. Presented at the SPE International Symposium on Oilfield Chemistry, Houston, February 13-16. SPE 65033. http://dx.doi.org/10.2118/65033-MS.

Chepick, S. K., \& Musabirov, M. Kh. (2006). Method of water isolation in downhole zone of the recovering formation. Claimer and patent owner OAO Tatneft named after V. D. Shashin.

Coulter, G. R. (1993). US 5197543 A. Horizontal well treatment method. Oryx Energy Company.

Dahayanake, M. S., Yang, J., Niu, J. H. Y., Derian, P.-J., Li, R., \& Dino, D. (1998-2001). US 6258859 B1. Viscoelastic surfactant fluids and related methods of use /; Rhodia, Inc.; US 09/093,131.

Espina, V., Guerrero, M., Colmenares, O., Dias, J. D., Rae, P., \& Lullo, G. Di. (2011). Significant increase in formation debit owing to canals creation with the help of acid. Oil and gas technologies, 2, 33-36.

Fjelde, I. (2008). Sulfate in Rock Samples from Carbonate Reservoirs. Paper was prepared for presentation at the International Symposium of the Society of Core Analysts held in Abu Dhabi, UAE 29 October-2 November.

Gomari, K. A. R., Karoussi, O., \& Hamouda, A. A. (2006). Mechanistic study of interaction between water and carbonate rocks for enhancing oil recovery. Paper SPE 99628 presented at the SPE Europec/EAGE Annual Conference and Exhibition held in Vienna, Austria, June 12-15. http://dx.doi.org/10.2118/99628-MS

Høgnesen, E. J., \& Standnes, D. C. (2006). Waterflooding of preferential oil-wet carbonates: Oil recovery related to reservoir temperature and brine composition. Paper SPE 94166 Presented at the 14th Europec Biennial Conference held in Madrid, Spain, 13-16 June.

Ibragimov, N. G., Ismagilov, F. G., Musabirov, M. Kh., \& Abusalimov, E. M. (2014). Results of experience-based industrial works in the field of downhole zone treatment and well stimulation in OAO "Tataneft". Oil economy, 7, 40-43.

Ibragimov, N. G., Musabirov, M. Kh., \& Yartiev, A. F. (2014). Efficiency of wells stimulation technologies complex. Oil economy, 7, 44-47.

Joshi, S. D. (1988). Augmentation of Well Productivity with Slant and Horizontal Well (pp. 729-739).

Kazemi, H. (1969). Pressure Transient Analysis of Natural Fractured Reservoirs with Uniform Facture Distribution. Soc. of Petroleum Engineers Journal, 9(12), 463-472. http://dx.doi.org/10.2118/2156-B

Lungwitz, B., Fredd, C., Brady, M., Miller, M., Ali, S., \& Hughes, K. (2007). Diversion and Cleanup Studies of Viscoelastic Surfactant-Based Self-Diverting Acid. In SPE 86504. Production \& Facilities, 2, 121-127.

Manchanda, R., \& Sharma, M. M. (2007). Impact of Completion Design on Fracture Complexity in Horizontal Shale Wells. Equilibrium Test-A Method for Closure Pressure Determination. Paper SPE 78173 presented at the SPE/ISRM Rock Mechanics Conference, Irving, Texas, October 20-13.

Matrix Stimulation. (2005). An SPE Applied Technology Workshop. Marriott Grand Hotel Moscow, Russia.

Musabirov, M. Kh. (2007). Preservation and enhancement of oil formation productivity (p. 423). Kazan: Fan.

Nasr-El-Din, H. A., Al-Nakhli, A., Al-Driweesh, S., Welton, T., Sierra, L., \& Van Domelen, M. (2007). Optimization of Surfactant-Based Fluids for Acid Diversion. SPE 107687 presented at the 7th SPE European Formation Damage Conference held in Scheveningen, The Netherlands, 30 May-1 June. http://dx.doi.org/10.2523/107687-MS

Oligney, R., \& Economides, M. (2001). Unified Fracture Design: Bridging the Gap Between Theory and Practice. Booklink Distribution.

Orlov, G. A., \& Musabirov, M. Kh. (2001). Method of acid treatment of oil formation. Claimer and patent owner OAO Tatneft named after V. D. Shashin.

Peaceman, D. W. (1983). Interpretation of Well-Block Pressure in Numerical Reservoir with Nonsquare Grid Blocks and Anisotropic Permeability. Soc. Petrol. Eng. J., 531-543. http://dx.doi.org/10.2118/10528-PA

Pobert, N. (1983). Tuttle. High-Pour-Point and Asphaltic Crude Oils and Condensates. Journal of Petroleum Technology, 35(7), 110-118.

Renard, G. I., \& Dupuy, J. M. (1990). Influence of Formation Damage on the Flow Efficiency of Horizontal Well Technology. 
Sheng, J. J. Review of Surfactant Enhanced Oil Recovery in Carbonate Reservoirs. Paper SPE 97687 Presented at the SPE International Improved Oil Recovery Conference in Asia Pacific held in Kuala Lumpur, Malaysia, December 5-6.

Webb, K. J., Black, C. J. J., \& Tjetland, A. (2005). Laboratory Study Investigating Methods for Improving Oil Recovery in Carbonates. Paper IPTC 10506 Presented at the International Petroleum Technology Conference in Doha, Qatar, November 21-23. http://dx.doi.org/10.2523/10506-MS

Xie, X., Weiss, W. W., Tong, Z., \& Morrow, N. R. (2005). Improved Oil Recovery from Carbonate Reservoirs by Chemical stimulation. Paper SPE/DOE 89424, Sept. 2005 SPE journal, $276-285$. http://dx.doi.org/10.2118/89424-PA

Yartiev, A. F. (2011). Investment projecting in oil recovery: innovations and economic estimation (p. 216). VNIIOENG.

Yartiev, A. F., \& Bazarevskaya, V. G. (2008). Perspectives of oil recovery development in Volga-Ural oil and gas province. Oil producing, 1, 20-24.

\section{Copyrights}

Copyright for this article is retained by the author(s), with first publication rights granted to the journal.

This is an open-access article distributed under the terms and conditions of the Creative Commons Attribution license (http://creativecommons.org/licenses/by/3.0/ 